\title{
Handelinge in die erediens: \\ Die verryking van die liturgie \\ deur musiek $^{1}$
}

\author{
Elsabé Kloppers \\ Hervormde Teologiese Kollege \\ Universiteit van Pretoria
}

\begin{abstract}
Actions in the worship service: Enriching liturgy through music

The worship service in the Reformed Churches in South Africa has of late come under pressure. On the one hand it is experienced as too rigid and "traditional". On the other hand superficial forms of renewal create tension. In this article the worship service and the meaning of the liturgical actions in the worship service of the Afrikaans Reformed Churches are discussed, and related to world-wide ecumenical tendencies. It is argued that certain liturgical actions are a necessary part of the ritual of the worship service. The structure needs inner logic, although there should also be some degree of flexibility. Hymns and music offer the means for a more creative presentation of liturgical actions and traditional forms. Suggestions to enrich the liturgy through the use of hymns and liturgical forms in the Liedboek van die Kerk (2001) are offered.
\end{abstract}

\section{INLEIDING}

Die erediens in die Reformatoriese kerke in Suid-Afrika staan onder druk. Eredienste word dikwels as te eenvormig en te "tradisioneel" ervaar. Pogings tot oppervlakkige vernuwing bring egter nuwe spanning. Die tradisionele en bekende gaan verlore en lidmate voel dikwels dat hulle nie meer weet waarvoor hulle hul in die erediens inlaat nie. Enersyds is die vorm dikwels te strak en óórbekend, en andersyds is daar dikwels géén vorm, geen inherente logika, en dus geen vertroudheid nie. Afwisseling in die liturgie bewerk 'n groter mate van bewustelike deelname. ' $n$ Verskeidenheid lied- en liturgiese

\footnotetext{
${ }^{1}$ Hierdie artikel is ' $n$ verwerking en uitbreiding van ' $n$ studiestuk wat tydens die 67 ste Algemene Kerkvergadering van die Nederduitsch Hervormde Kerk van Afrika (September 2004) vir opname in 'n nuwe Diensboek aanvaar is. Uitgebreide liturgiewetenskaplike en himnologiese navorsing (Kloppers 1994 - 2005) lê die studiestuk ten grondslag.
} 
vorme bied die geleentheid om die liturgie kreatief in te rig en só die liturgie te verryk. Dit versterk ook die geleentheid tot aktiewe deelname deur die gemeente (Kloppers 2003b; 2002b:14-22; Vrijlandt 1995).

In dié artikel word die erediens en die betekenis van die handelinge in die erediens bespreek. Vanuit die breë Reformatoriese tradisie, sowel as die doelstellings van liturgiese bewegings wêreldwyd (Oskamp \& Schuman 1998; Best \& Heller 1996; Schmidt-Lauber 1995; Wolterstorff 1992; Adam 1992:93102, 345-351; Neunheuser 1987) word 'n basis vir die verstaan en inrigting van eredienste in die Reformatoriese Kerke in Suid-Afrika gegee, en aangetoon hoe vorme uit die breër liturgiese tradisie die erediens kan verryk. Uitgangspunte en riglyne sluit aan by dié van kerke met 'n sterk ekumeniesliturgiese bewussyn (vgl onder meer Dienstboek 1998; Reformiertes Gesangbuch 1998; Evangelisches Gesangbuch 1993) en word aangevul met voorstelle vir die gebruik van liedere en liturgiese vorme in die Liedboek van die Kerk (2001). ${ }^{2}$ Die eie aard van die meeste Reformatoriese kerke in SuidAfrika, onder meer betreffende soberheid in die ritueel van die erediens, is steeds in ag geneem.

\title{
2. DIE EREDIENS: FUNDAMENTELE UITGANGSPUNTE
}

\begin{abstract}
Von seinem Wesen her ist der Gottesdienst darauf angelegt, so deutlich und so öffentlich wie möglich das Gedächtnis von Gottes Großen Taten su feiern, und gleichzeitig so frei und so gelassen wie nötig den einzeln in der communio sanctorum daran teilhaben zu lassen.
\end{abstract}

Möller 1988:23

In die erediens ontmoet God die gemeente deur die werking van die Woord en die Heilige Gees. Die gemeenskap wat in die erediens saamkom word deur God self saamgeroep, daarom is dit die gans ander gemeenskap, die geloofsgemeenskap, wat byeen is. Die erediens is 'n nie-alledaagse byeenkoms, wat anders lyk as die wêreld daar buite (Heimbrock 1993:24; Schmidt-Lauber 1995:35; Assmann 1991), al is die erediens ingebed in die alledaagse lewe, en al kom die gemeente vanuit die alledaagse wêreld en gaan weer daarheen terug. Die erediens is 'n simboliese handeling, wat ook as 'n christelike ritueel of rituele handeling beskryf kan word (vgl Wegman

\footnotetext{
${ }^{2} \mathrm{Vgl} \mathrm{die} \mathrm{konkrete} \mathrm{bydrae} \mathrm{aan} \mathrm{nuwe} \mathrm{liedere} \mathrm{en} \mathrm{vernuwende} \mathrm{liturgiese} \mathrm{vorme} \mathrm{(Voorwoord:}$ Liedboek van die Kerk 2001; Kloppers 2005, 2001) en Viljoen (1999:120-121) wat aantoon dat die navorsing van Strydom (1994) en Kloppers (1997) die rigting vir eietydse vernuwing ten opsigte van die kerklied deurslaggewend aangedui het.
} 
1991; Kloppers 1997:116-132; Josuttis 1997; Bell 1997; Lukken 1999; Barnard \& Post 2001, Barnard 2000).

God se Woord word deur die handelinge en simbole in die liturgie, soos die preek, die sang, gebede, belydenisse en so meer, gesimboliseer oftewel vergestalt (Bastian 1991:343). God is egter nié outomaties in en deur al hierdie handelinge teenwoordig nie. God is outonoom en bepaal self sy teenwoordigheid. Volgens Noordmans (1986:77) kan ons nie sê dat God kerktoe gaan wanneer ons kerk-toe gaan nie! Die ontmoeting met God is ook nie vanselfsprekend nie. Die "gans ander gemeenskap" kan net biddend wag op die ontmoeting met God. Hierdie ontmoeting lei tot gemeenskap tussen God en die gemeente en tussen die gelowiges onderling. Die Heilige Gees maak die ontmoeting met God en die gemeenskap met mekaar moontlik (Joh 4:24; Rom 12; Ef 2:22; 2:18; Ef 4). 'n Fundamentele kenmerk van die liturgie is dus die dubbele beweging wat voltrek word waar die gemeente bymekaar is (Immink 1998:69-75).

Die erediens is die voedende bron waaruit die liggaam van Christus leef (vgl Rom 12). Waar die erediensgebeure afgewater word, "so schneidet man auch den Wurzeln ab, aus denen bei Paulus das Bild vom Leib und den Gliedern in der Kraft des Geistes erwächst" (Möller 1988:23). Deur aktiewe deelname aan die erediens is die gemeente ook by mekaar betrokke. Die predikant, as geordende, gevolmagtigde dienaar van die Woord, verrig inderdaad bepaalde funksies (soos die preek en die seëngroet), maar alle (ander) handelinge kan en behoort ook deur die gemeente verrig te word. Daardeur kom die priesterskap van alle gelowiges konkreet tot gestalte.

Die gemeente leef vanuit die unieke byeenkoms van die erediens in die wêreld en na die wêreld toe. Volgens Bonhoeffer is die gemeente die "Gemeinde für andere" (Bethge 1967:992). Die gemeente leef daagliks die erediens van die lewe en kom reëlmatig weer in die gesamentlike byeenkoms van die gelowiges op die Sondag, die dag van die opstanding (Monshouwer 1998:102-105), saam (Luk 24:13; Joh 20:19-26, Hand 20:7). Die viering van Sondag tot Sondag vorm dus die ritme waarmee die Christelike kerk leef - dit is die "weeklikse pase" (Van Tongeren 2001:73).

Die gemeente vier altyd die ontmoeting met die opgestane Heer - met verskillende klemtone in die verskillende tye van die jaar (Saliers 1994:103110). Die samekoms van die gelowiges staan ook altyd binne 'n bepaalde tyd in die jaar en die kerkjaar vorm ook die polsslag van die kerk (Harnoncourt 1994, 9-63). Die erediens bevat dus handelinge wat fundamenteel in elke erediens tuishoort, maar die spesifieke aard en inhoud van 'n erediens word deur die tyd in die kerkjaar bepaal. Spesifieke geleenthede in 'n gemeente/ 
gemeenskap se lewe en bepaalde wêreldgebeure, kan - en behoort! - ook ter sprake gebring te word (Earey \& Myers 2001:230-233; Assmann 1991:13-30).

Deur die werk van die Heilige Gees word die erediensgebeure 'n geheelervaring waar die gemeente tot geloof kom, opnuut tot geloof kom, en getransformeer word tot radikaal nuwe mense (Kloppers 2003d:122-125). Die erediens as die besondere ontmoeting met die lewende God, wat ons byeenroep en wat steeds nuut met ons handel, is ' $n$ geleentheid om altyd weer opnuut deur God se aanspreke verander te word. Die erediens behoort dus nooit in geykte vorms te verval nie.

'n Basiese grondstruktuur as die binding aan die oorgelewerde geloofstradisie (vgl Wolterstorff 1992:278), behoort behou te word, maar nuut en kreatief ingeklee te word (Holze 1992; Kloppers 1999a:293-294). Dit beteken dat daar binne die basiese grondstruktuur verskuiwings mag wees, maar dat handelinge nié lukraak en deurmekaar mag plaasvind nie. Die volgorde van handelinge moet altyd liturgies-teologies gemotiveer kan word. Elke handeling moet sinvol by die voorafgaande en die daaropvolgende handeling aansluit, en moet saam 'n sinvolle eenheid en geheel van verkondiging vorm.

Die erediens bestaan uit vier groot dele: Opening, Woorddeel (wat bestaan uit skriflesings, preek, response, liedere, belydenisse en gebede), Nagmaal en Wegsending (Wolterstorff 1992:278; Adam 1992:143-144). 'n Erediens sonder die Nagmaal is onvolledig (Wolterstorff 1992; Möller 1988:201-204).

\section{BOUSTENE VAN DIE LITURGIE}

\subsection{Voorbereiding/Openingsdeel}

- Stil voorbereidingsgebed en orrelspel

Die gemeentelede moet hulleself voorberei op hierdie unieke byeenkoms in God se teenwoordigheid. Die gemeente moet konkreet bewus raak van die rede vir die byeenkoms én die aard van die byeenkoms - dat dit 'n byeenkoms is waarheen hulle kom om God te ontmoet of nuut te ontmoet en waar hulle in gemeenskap met God en met mekaar tree. Daarom is dit gepas dat die gemeente vanuit die geraas van die alledaagse wêreld eers in stil voorbereiding en met stil gebed byeenkom. Josuttis (1991:99) stel dit treffend: "Stilte dui die kommunikatiewe grens met die buitewêreld aan." Indien daar orrelspel is, moet dit funksioneel wees daarin dat dit die stil gebed dra en reeds die aard en tema van die erediens reflekteer. Stilte is 'n belangrike gronddimensie van die erediens (Ehrensperger 1996:139; Peeters 2001:155- 
161). Stilte dra gebed, voorbereiding en nadenke (Van Tongeren 2001:200201). Sinvolle stiltes behoort dus deel te vorm van elke liturgie (Kloppers 1997:211-213).

\section{- $\quad$ Verwelkoming en afkondigings}

Die afkondigings hou verband met die werksaamhede van die gemeente as geheel. Gesproke afkondigings moet egter tot die minimum beperk word. Afhangend van die aard van elke erediens, kan dit aan die begin of einde van die erediens kom. $^{3}$

\section{- $\quad$ Voorafsang/sangoefening}

Die volle gemeente moet by die voorafsang teenwoordig wees. Tydens die sangoefening kan 'n nuwe lied aangeleer word, wat in die erediens, of in 'n volgende erediens gebruik gaan word. Liedere moet aangeleer word met die oog op gebruik - 'n lied word nie bloot aangeleer omdat dit 'mooi' is nie. Die moontlike funksie in die erediens moet van die begin af aan die gemeente voorgehou word. Indien 'n nuwe lied nie aangeleer word nie, kan een of twee liedere gesing word wat die aard en tema van die erediens dra. Die voorafsang mag nie die lofsang in die erediens die krag ontneem nie. Die keuse van liedere en die lengte van die voorafsang moet dus noukeurig bedink word.

\section{- $\quad$ Toetrede- of toewydingslied}

Dit is noodsaaklik dat daar ná die afkondigings en voorafsang weer genoeg stilte kom om die gemeente tyd te gee tot inkeer en voorbereiding op die gebeure wat kom. Die toetrede of toewydingslied behoort die karakter van afwagting, toewyding en ingetoënheid te hê. Die toetredelied behoort ook kort te wees. Die lofsang behoort nié vooruitgeloop te word nie. ${ }^{4}$

Die meeste liedere onder die opskrif Toetrede en Aanroeping is geskik, alhoewel sommige strofes in dié rubriek eerder as lofsang behoort te funksioneer. 'n Moontlike wyse van gebruik is dat een of twee strofes van 'n lied wat 'n toewydingskarakter het, as toetredelied gesing word, terwyl dié met

\footnotetext{
${ }^{3}$ Die motivering om dit aan die begin van die erediens te plaas, is meervoudig. Dit is ' $n$ geleentheid om formaliteit en vreemdheid te oorkom. Daar word ook verhoed dat die samekoms en voorbereiding van die gemeente 'n alledaagse "gekuier" word, in plaas van gebed en stil voorbereiding op die erediensgebeure. Dit bied ook 'n geleentheid om die gemeente en besoekers met warmte te verwelkom en nuwe intrekkers aan die gemeente voor te stel. Sekere liturgiese handelinge of visuele voorstellings in die bepaalde liturgie kan hier ook kortliks toegelig word.

${ }^{3}$ Maritz (2003:13) verwys na LvdK 201 wat voor 'n "groot" erediens in Augustus as toetredingslied gesing is. Dit is ' $n$ kerslied met ' $n$ entoesiastiese melodie (in die negatiewe sin) waar die melodie vereis dat die slotreël op opruiende wyse driekeer herhaal word. Só 'n gebruik is 'n vooruitloop op die lofsang.
} 


\section{Handelinge in die erediens}

'n lofkarakter as lofsang gesing word, (bv LvdK 159:1 en 2 as toetrede en strofe 3 as lofsang; so ook met LvdK 154). Op dié wyse vervul verskillende strofes 'n definitiewe funksie en word ook 'n bepaalde eenheid verkry.

\section{- Votum}

Die votum is gewoonlik 'n kort skrifsitaat of opening in die Naam van God. Dit beklemtoon dat God self sy gemeente byeenroep en teenwoordig wil wees. Dit kan 'n roep om God se teenwoordigheid en hulp wees. Die votum kan dus deur die predikant óf 'n gemeentelid namens die volle gemeente uitgespreek word (volgens Nederlandse Dienstboek 1998:862, éérder 'n lidmaat). Die gemeente kan met 'n gesproke of gesonge Amen of kort respons antwoord.

Die votum kan ook deur 'n kantor of kantory gesing word, (bv LvdK 272, 446, 180):

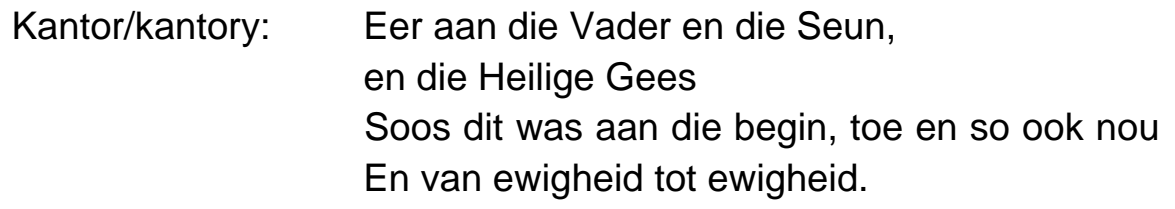

Gemeente (sing): Amen

(LvdK 180)

\section{- $\quad$ Seëngroet}

Die groet se oorsprong lê in die Ou en die Nuwe Testament. As gevolmagtigde spreker, groet die predikant die gemeente namens God Drieenig en strek die hande uit oor die gemeente. Die gemeente kan met 'n gesproke of gesonge Amen antwoord. (Kyk ook Oskamp 2001:205-216).

Die Apostoliese groet is die bekendste:

$$
\begin{aligned}
& \text { Predikant: } \quad \begin{array}{l}
\text { Genade en vrede vir julle van God ons Vader, } \\
\text { van Jesus Christus, die Here en van die Heilige Gees. }
\end{array}
\end{aligned}
$$

\section{Gemeente: Amen}

Die gemeente kan ook op die seëngroet antwoord met 'n respons (bv LvdK 181). 
- $\quad$ Lofsang (Gloria)

Die lofsang kan direk ná die votum en seëngroet gesing word - die mees algemene gebruik in die reformatoriese-gereformeerde tradisie. Die lofsang behoort egter ook ná die skuldbelydenis en genadeverkondiging te klink, omdat die vryheid wat God gee, ervaar word, en die gelowiges nie anders kan as om God se lof te verkondig nie. So gesien het die lofsang selfs sterker grond. Die loflied van die engele (Luk 2:14) gee die toon van die Gloria aan. So ontstaan daar 'n communio sanctorum van die hemelse en aardse gemeente (Müller 1955:29). Die lofsang word in ingetoë tye soos Advent en Lydenstyd, getemper en selfs weggelaat (Adam 1992:147). Voorbeelde vir die lofsang is LvdK 182-227, en afhangend van die tyd in die kerkjaar en die tema van die erediens, 'n groot aantal lofsange in die afdelings Die liturgiese jaar en Die erediens van die lewe. Die Groot Gloria is opgeneem by LvdK 445 en 446.

\section{- $\quad$ Skuldbelydenis (Kyrie eleison)}

Die wete dat die mens skuldig staan voor God, bring die mens tot skuldbelydenis: confiteor - ek bely .... Wanneer die skuldbelydenis aan die begin van die erediens staan, word daarmee die huiwering en onmag om voor God te verskyn, bely ${ }^{5}$. Die skuldbelydenis verder in die erediens wat sterker in verband met die preek staan, verklank die onmag om God se wil te doen en te leef soos God verwag. Die skuldbelydenis kan gesê of gesing word. Daarvoor is die liedere onder Skuldbelydenis en genade veral geskik.

Reeds in die liturgie van die vroeë kerk staan die roep Kyrie eleison as gesonge of gesproke respons in noue verband met die skuldbelydenis. Die roep is reeds in die voor-Christelike antieke bekend as 'n huldigings- en jubelroep aan die heerser met sy intog. Later word dit op Jesus Christus oorgedra as die Heer van alle Heersers. Die roep is aanvanklik net in die Christelike erediens van die Oosters-Ortodokse Kerke gebruik, maar vind rondom die jaar 500nC die weg na die Westerse kerke as 'n soort volksgesang (Wyss-Jenny 1998:50). In die loop van die liturgiegeskiedenis ontwikkel uit die jubellied ook geleidelik meer 'n gebedsroep (Bittruf).

Die Kyrie-roep se oorspronklike plek is by die litanieë (ektenies) - die gebed om God se ontferming by die voorbedes, maar dit het geleidelik die plek aan die begin van die erediens gekry - sonder die voorbedes (Adam 1992:146). Die Liturgiese Bewegings van die twintigste eeu het die gebruik van die Kyrie herontdek as 'n element van bykans al die historiese liturgieë

\footnotetext{
${ }^{5}$ Calvyn het die skuldbelydenis ook vroeg in die erediens geplaas, gevolg deur die vryspraak. Die Wet is daaropvolgend gesing, met Kyrie eleison in Grieks ná elke gebod (Honders 1988:19). Hierdie gebruik is egter net in Straatsburg gevolg en nie in Geneve nie (Luth 2001).
} 


\section{Handelinge in die erediens}

(Mumm 1987:763). Dit word ook in die oorspronklike taal, naamlik Grieks gesê/gesing (nie Latyn of "latyns", soos Maritz 2001:12 skryf nie), ongeag die taal waarin die res van die liturgie plaasvind (vgl Grisbrooke 1984:291). As sodanig is die Kyrie eleison by uitstek 'n ekumeniese bindingselement. Die Kyrie as kollektiewe respons bied die geleentheid vir aktiewe deelname van die volle gemeente en behoort so ver as moontlik deur die volle gemeente gesing te word (Van Nijen 1998:178; Adam 1992:146; Lamberts 1985:100):

\begin{tabular}{|c|c|c|}
\hline Liturg: & $\begin{array}{l}\text { Ons het almal g } \\
\text { Niemand is ons }\end{array}$ & $\begin{array}{l}\text { lig. } \\
\text { voor U nie. }\end{array}$ \\
\hline Gemeente: & $\begin{array}{l}\text { Kyrie eleison } \\
\text { Christe eleison } \\
\text { Kyrie eleison }\end{array}$ & $\begin{array}{l}\text { Here, ontferm } U \text { oor ons. } \\
\text { Christus, ontferm } U \text { oor ons } \\
\text { Here, ontferm } U \text { oor ons. }\end{array}$ \\
\hline
\end{tabular}

(Die Kyrie eleison is opgeneem in LvdK 242, 243, 246-248, 307.)

\section{- $\quad$ Genadeverkondiging}

Die genade en vryspraak kan deur die liturg of mede-liturg (ouderling of gemeentelid) verkondiging word. Die gelowiges kan die vryspraak ook aan mekaar verkondig deur die sing van 'n lied (bv LvdK 241, 244, 245). Deur die belydenis van skuld kan die vryspraak reeds ervaar word, waarop die lofsang direk kan volg. Die genadeverkondiging hoef dus nie eksplisiet in elke erediens as afsonderlike handeling na vore gebring te word nie - dit kan ook in die preek en liedere tereg kom. Die gebed om genade/ belydenis van skuld deur die volle gemeente, hoort egter in elke erediens.

\section{- $\quad$ Die wil van God}

In kerke in die gereformeerde tradisie speel die Tien Gebooie 'n belangrike rol. Erediens en lewe word daardeur nou op mekaar betrek. Die Dekaloog het 'n belangrike plek aan die begin van die erediens. Wanneer die wet direk ná die votum en seëngroet gelees word, het die gebod die intensie om die gemeente skuldig te stel voor God en op te roep tot skuldbelydenis (vgl Immink 1998:185-194). Wanneer dit ná die genadeverkondiging gelees word, funksioneer dit as reël vir dankbaarheid. Die wil van God, as reël vir 'n lewe van dankbaarheid, eerder as 'n wettiese voorskrif, behoort trouens sterker te funksioneer. ${ }^{6}$ Dit is uitdrukking van die wyse waarop God wil hê dat daar in sy nuwe wêreld geleef moet word (Balentine 1999:201; Brueggemann 1997:55). Die wil van God bestaan dus nie slegs uit die Dekaloog nie (Cilliers 2003:33-

\footnotetext{
${ }^{6}$ Volgens Jenny (1968:133) het Calvyn die Wet op verskillende wyses gebruik, maar ooreenkomstig Kol 3:1 dit veral as 'n reël vir 'n lewe van dankbaarheid beklemtoon.
} 
36), maar kan in ' $n$ verskeidenheid van vorme, en deur verskeie ander skrifgedeeltes ter sprake gebring word - ook in die preek en liedere, byvoorbeeld $249-251,526,530,19: 3-5,97: 5$ (sien die gebruik by Calvyn, voetnoot 7). In 'n diens waar die fokus op die kind is, kan 'n kind/kinders die Wet, of 'n skrifgedeelte of lied wat die Wil van God verklank, lees of sing. Dit kan ook in die preek en liedere ter sprake kom.

\section{- $\quad$ Epiklese gebed}

Die gebed om teenwoordigheid en bystand van die Heilige Gees kan deur die predikant, ouderling of gemeentelid gebid word. Die volle gemeente, kantor of kantory kan dit ook sing, byvoorbeeld LvdK 151:2, 166; 162:2 en 3; 166; 252258; 270; 272; 430-432; 436; 442, 452.

\subsection{Woorddeel}

\section{- $\quad$ Skriflesing(s)}

Die Skriflesing is met die prediking en die kerklike jaar verbind. Dit is 'n selfstandige liturgiese handeling wat sterker fokus behoort te kry. In klassiekgereformeerde/hervormde gemeentes word die keuse van die lesing deels deur die kerkjaar en deels deur die vrye keuse van die predikant bepaal (Immink 1995:133). Die skriflesings kan en behoort selfs deur lidmate gedoen te word. Daarmee word gesimboliseer dat die predikant hom/haarself ook onder die Woord van God stel en daarna luister (Adam 1992:149). In die liturgiese tradisie word meerdere skriflesings uit verskillende dele van die Bybel belangrik geag, naamlik lesings onderskeidelik uit die Ou Testament, die briewe en die evangelies.

Op die verskillende lesings kan telkens met bepaalde response geantwoord word soos die Halleluja (LvdK 189, 204, 218) wat veral voor die evangelielesing funksioneer, of 'n kort loflied (LvdK 161, 185, 206, 228). Eredienste kan verryk word deur die gebruik van hierdie liedvorme, selfs wanneer net uit een Bybeldeel gelees word. Onmiddellik ná die respons op die Skriflesing(s) kan 'n langer lied wat die tema van die skriflesing(s) verklank, ook gesing word.

'n Liturgiese vorm soos die Halleluja behoort in lyn met die ekumeniesliturgiese tradisie gebruik te word: slegs in verband met die Skriflesings en nie ongemotiveerd en na willekeur op enige plek in die liturgie nie - veral nié na die votum soos Van der Merwe (2003:5) voorstel nie. In die Lydenstyd behoort die Halleluja nie gesing te word nie (vgl onder meer Dienstboek 1998:156). In dié tyd is ander response eerder gepas, soos LvdK 181, 221, 222, 379. 
Response behoort op 'n gedrukte liturgie te verskyn en sonder aankondiging gesing te word, óf dit moet voor die bepaalde Skriflesing aangekondig word. Op die kort aankondiging aan die einde van 'n Skriflesing, byvoorbeeld Dit is die Woord van God, word die respons spontaan gesing. Dit is noodsaaklik dat die orrelis opgeskerp moet wees om met die inleiding die gemeente tot reaksie te bring.

\section{- $\quad$ Preek}

In die Reformatoriese kerke word die preek deur die predikant, wat die amptelike opdrag daartoe het, gelewer. ${ }^{7}$ Die preek is deel van die Woorddeel, saam met die Skriflesing(s), geloofbelydenis en liedere. Dikwels word die liturgie beskou as net 'n omraming van die preek. Die preek as praedicatio Dei, moet egter nie met die totale "verkondiging van God se Woord" gelykgestel word nie. Die tema van die erediens, wat deur die Skriflesing(s) en kerkjaar bepaal word, moet deur elke liturgiese handeling, Skriflesing, lied, teks en beweging gedra, uitgebou, saamgevat en geïntegreer word, en tot 'n hoogtepunt in die preek kom. So vorm die erediens as geheel 'n eenheid (Kloppers 2003a). Die lied in aansluiting by die preek of preeklied bevestig die tema van die preek én die erediens.

\section{- Geloofbelydenis}

Die belangrikste twee trinitariese geloofbelydenisse in die liturgiese tradisie is die Apostoliese Geloofbelydenis (Twaalf Artikels) en die Geloofbelydenis van Nicea-Konstantinopel. Vanweë die ekumeniese tradisie en dus as deel van die bekende boustene van die ritueel van die liturgie, funksioneer dié belydenisse hoofsaaklik in die erediens (Stollberg 1984:28). Die geloof behoort egter ook in eietydse formulerings bely te word, daarom kan ander geloofsformulerings, soos dié in 'n lied, soms by wyse van afwisseling gebruik word. Wanneer die geloofbelydenis voor die preek kom, is die preek 'n lofprysende bevestiging van die geloofbelydenis (Stollberg 1984:36). Wanneer die geloofbelydenis ná die preek volg, word daarmee uitgedruk dat diegene wat die Woord van God hoor, opnuut tot geloof kom en die geloof opnuut bely (Webber 1985:53).

Die geloofbelydenis kan deur die predikant of gemeentelid namens die gemeente gesê word, of namens die gemeente deur 'n kantor of kantory gesing word. Die geloofbelydenis hoort egter in die mond van die volle gemeente, wat dit gesamentlik kan sê of sing (by Calvyn was dit 'n gebruik om

\footnotetext{
${ }^{7}$ In die Rooms Katolieke Kerk kan die preek, uitgesonderd die Mishomilie (Meßhomilie) ook deur leke waargeneem word. "Leke" is egter dikwels mense met 'n grondige teologiese opleiding, wat selfs eredienste waarneeem, maar wat nie georden mag word as priesters nie, byvoorbeeld vroue en getroude mans.
} 
die geloofbelydenis te laat sing). So byvoorbeeld kan LvdK 259 - 265; 179; 445 - 453 gebruik word. Hierdie liedere en ander toewydingsliedere kan ook as bevestiging op die gesproke geloofbelydenis gesing word. Die geloofbelydenis dien as bevestiging van die doop (die Apostolicum word veral met die doop geassosieer) en ook as gemeenskaplike geloofsbevestiging met die oog op die viering van die sakramente (Barnard 1998:207; Berger 1987:28).

- Gebede

Gebede kan gesê en gesing word. In die Liedboek van die Kerk is 'n groot verskeidenheid gebede opgeneem. Gebede in die liturgiese tradisie is onder meer die groot dankseggingsgebed ná die preek en geloofbelydenis, die algemene gebed met voorbedes, en die Ons Vader.

\section{- $\quad$ Danksegging}

Die groot dankseggingsgebed vind by die Nagmaal plaas, of direk ná die preek, wanneer die sakrament nie bedien word nie. Die dankgebed kan ook gesing word (bv LvdK 529). "Alle Feier des Gottesdienstes ist Danksagung vor Gott; auch jede Bitte ist dankbare Anerkennung seiner Macht und Güte" (Berger 1987:29).

- $\quad$ Algemene Kerkgebed - Voorbede of Litanie Ooreenkomstig die aanwysings in 1 Tim 2:1-7 bestaan die algemene gebed uit die bede vir die kerk, die regeerders, die wêreld, vir die nood van die mense en vir die sorge van die versamelde gemeente (Stock 2001:309-313; Küppers 1987:427; Stollberg 1984:29.) Daarmee word die priesterlike diens van alle gelowiges verrig. Soos Christus, vereenselwig hulle hulself met die armes en die swakkes. Die gebed kan in die vorm van 'n litanie wees: spesifieke voorbedes met response, soos in die vroeë kerk, waar 'n reeks kort gebede (litania) aan die einde van die vespers (aanddiens) deur die diakens gebid is, en waarop die gemeente telkens met Kyrie eleison geantwoord het (Müller 1995:14-15). "Of all forms of public prayer, the litany is perhaps the most flexible and the most conducive, when used competently, to effective congregational participation in the liturgy" (Grisbrooke 1984:307).

Vanaf die vroegste tye is die bedes vir die armes en die nood van die mense deur die diakens gebid. In die erediens kan die (litanie)gebed dus deur die predikant, diakens of gemeentelede gebid word. Verkieslik moet die gebed deur die predikant ingelui en afgesluit word, terwyl gemeentelede die ander bedes bid. Elke bede word telkens afgesluit met 'n gesproke frase soos: So bid ons Here. 'n Oomblik van stilte kan hierdie frase voorafgaan én daarop 
volg. Die volle gemeente antwoord telkens deur te sing of te sê: Hoor ons bid, o Heer (bv LvdK 278). ${ }^{8}$

Die Amen word eers aan die einde van die gebed gesing. Die gemeente kan ook antwoord met Kyrie eleison, Heer, wees ons genadig (LvdK 247), soos in vierde-eeuse liturgieë uit Jerusalem en Antiochië (Grisbrooke 1984:291; 306). Die begeleiding is altyd sag en ingetoë. 'n Baie kort inleidende frase word gegee, sodat die gemeente hulle kan oriënteer ten opsigte van die toonhoogte, tempo en volume.

\section{- Ons Vader}

Die Ons Vader (Matt 6:9-13), is een van die belangrikste ekumeniese simbole wat in elke erediens gebid behoort te word ${ }^{9}$. Uit ekumeniese oorwegings behoort dit veral gesamentlik gesê te word: "The Christian Churches have generally agreed that the prayer was intended for corporate use, and incorporated it into public worship" (Earey 2001:70 - my kursivering). Die gewilde toonsetting van 'n Afrikaanse teks op die melodie van ene Luther Emerson uit die ou Hallelujabundel (LvdK 266) is minder geskik, omdat die ekumeniese band nie deur dié weergawe gereflekteer word nie. Die Ons Vader van Luther (LvdK 267) het sterk ekumeniese betekenis.

Waar die sakrament nie plaasvind nie, volg ná voorafgaande gebed of gebede die Wegsendingdeel. Waar die erediens ooreenkomstig die oudkerklike en ekumeniese tradisie met die Nagmaal gevier word, volg die Nagmaal direk na die Algemene Kerkgebed met die voorbedes en word die Ons Vader tydens die Nagmaal gebid.

\subsection{Nagmaal/Sakramentdeel}

Die Nagmaal word hier nie in besonderhede bespreek nie, maar kom in 'n volgende artikel meer uitgebreid ter sprake.

\subsection{Wegsending}

\section{- Wegsending en lied}

Die gemeente word weggestuur om hulle roeping in die wêreld te gaan vervul. Vanselfsprekend kan die wegsending ook vóór die seën kom (Van Leeuwen

\footnotetext{
${ }^{8}$ Dit is 'n respons, wat ná die bedes hoort en wat dus nie vóór die gebed gesing behoort te word, soos Van der Merwe (2003:5) aanbeveel nie. Die verdere stelling in die berig, dat LvdK 278 "as lied binne die gebed" gebruik kan word, kan ook misverstand skep: liedere behoort nie "binne gebede" gebruik te word nie. Kort response kan ná bedes (dus as 't ware klein gebede wat telkens 'n eenheid vorm) funksioneer.

${ }^{9}$ Die voorbedes, gevolg deur die Ons Vader, was 'n vaste deel van die liturgie by Calvyn. Wanneer die Nagmaal gevier is, het die Onse Vader verskuif. Dit het dan by die Nagmaalviering as afsluiting van die geloofsbelydenis gefunksioneer - ná die gebed om konsekrasie van die brood en vóór die instellingswoorde (Maxwell 1984:460).
} 
1998:265). Die plek van die lied kan ook wissel. Die liturg kan 'n

wegsendingspreuk sê waarop die gemeente singend antwoord. Die gemeente kan ook deur middel van 'n wegsendinglied hulle roeping en verantwoordelikheid op hulle neem (bv LvdK 311; 533; 534). Van der Zee (1992:125) skryf: "bij het uitgaan mag best gezongen worden. Het was toch een feest?"

\section{- Seën}

Die predikant spreek die seën oor die gemeente uit. Dit is 'n bevestiging dat God die gelowiges in die wêreld uitstuur en vergesel. Die seën is nie wegsending nie, maar 'n egte toespreek van die seën van God. Dit moet daarom nie verander word in 'n moraliserende oproep tot goeie werke in die wêreld nie (Stollberg 1983:32). Die seën word gedra deur die bewussyn dat God se begeleiding ons vergesel buite die kerklike fees, die lewenswêreld in (Grethlein 1998; Rothfahl 2001:152-153). Die gemeente kan op die seën antwoord met 'n Amen of ander kort respons. Die gemeente kan ook die seën aan mekaar toesing (bv LvdK 269 en LvdK 316 of LvdK 268 waar hul met ons vervang kan word).

- $\quad$ Insameling van die offergawes, orrelspel, uittoglied

Die offergawes kan na die Nagmaal en deur die diakens tydens die uitstap van die gemeente, opgeneem word. Dit is ook simbool van die gemeente wat hulle volle gawes en in besonder dit wat hulle in die erediens ontvang het, verder gaan uitdeel. Die naspel is nog deel van die erediens en bevestig die aard van die erediens. Die gemeente kan ook singend uitstap (bv LvdK 317).

\section{RIGLYNE VIR PRAKTIESE IMPLEMENTERING}

Met die oog op die praktiese implementering van voorstelle is 'n paar riglyne noodsaaklik. Vertroudheid en sekerheid is belangrik om steeds geborgenheid in die erediens te ervaar. Vir die erediensganger om hom/haar volledig in die gebeure van die erediens in te laat, moet daar genoegsame oriëntering en sekerheid ten opsigte van die verloop en afloop van die erediens bestaan (Daiber 1978:97; 1992:15; Kloppers E \& W 2003:2-3).

Oriëntering word prakties gebied deur 'n gedrukte liturgie in die hand. Deur middel van 'n gedrukte liturgie kan die erediensganger onmiddellik 'n oorsig kry oor die tema en subtemas, van dit wat in die erediens gaan gebeur, en dit wat van hom of haar verwag gaan word. Sodoende kan die lidmaat of besoeker hom/haar reeds voorberei op die geheel van die erediens wat ter sprake is, sowel as op besondere handelinge. Die voordeel van 'n gedrukte 


\section{Handelinge in die erediens}

liturgie is dat die liturgie meer spontaan kan verloop, sonder voortdurende aankondigings of marching orders (vgl Wolterstorff 1992:273).

Op 'n gedrukte liturgie kan die tekste van die votum, seëngroet, liedere en selfs sommige gebede, gegee word. Die response (kort gesonge of gesproke reaksies op lesings of sitate) kan dan ook effektief funksioneer spontaan en sonder aankondiging. Op 'n gedrukte liturgie kan die visuele voorstellings en/of bepaalde handelinge kortliks toegelig word, en die verband tussen liedere en tekste uitgewys word. So kan lidmate hul vooraf reeds op die omvattende betekenis van die liturgiese gebeure voorberei en hulle oriënteer op die ruimte waarin hulle hul bevind. Die geheelbeeld, die volle "shape of the service" (Earey \& Myers 2001:91) wat voortdurend beskikbaar behoort te wees vir oriëntering, vir vooruitverwysing en terugverwysing, word die beste met 'n gedrukte liturgie in die hand verkry. Liedere en elektroniese beelde kan aanvullend tot 'n gedrukte liturgie gebruik word. Dit is egter belangrik dat die mees gepaste medium vir alle inhoude en handelinge gebruik word (Kloppers W C 2003:85-89)

Die orrelis as mede-liturg speel 'n bepalende rol om gebeure in die erediens vlot te laat verloop en veral om response spontaan te laat funksioneer. Die orrelis moet dus besonder voorbereid en opgeskerp wees om die regte leiding te gee sodat die gemeente met sekerheid kan reageer. Response behoort deur die volle gemeente gesing of gesê word, maar dié rol kan deur 'n kantor (voorsanger) of kantory vervul word, totdat 'n gemeente vertroud is daarmee.

Alle liggaamshoudings soos die sit of staan van die gemeente moet gemotiveer wees en moet pas by die funksionering van ' $n$ bepaalde handeling op 'n bepaalde plek (Josuttis 1991). Dit beteken dat 'n gemeente nie bloot meganies staan met die sing van 'n lied nie. Die aard van die lofsang vra meestal vir 'n staande houding, maar 'n stiller, meer ingetoë lied kan sittend met 'n meer ingetoë houding gesing word. Die liturg moet die aard van elke handeling, elke lied en elke gebed vooraf bedink en die houding van die gemeente (sittend of staande) dienooreenkomstig op die gedrukte liturgie aandui. Die liturg moet seker maak dat die oorgange sinvol en sonder onnodige beweging van sit en staan, verloop. Deur die liggaamshoudings konkreet te bedink, word die liturg nog meer gedwing om die erediens as geheel tot 'n sinvolle eenheid te beplan.

\section{SAMEVATTING}

Die betekenis van die liturgie lê nie in die vaste vorm en taalformules nie (Bell 1997:222-267). Bestaande vorme bied die geleentheid tot nuwe interpretasie. 'n Gemeente behoort liturgies toegerus te word om die aard van verskillende 
eredienste te kan begryp. Ten einde van die erediens 'n sinvolle eenheid te maak, moet die liturg(e) en eredienswerkgroep in die beplanning nadink oor die keuse van elke lied, teks, beeld (vgl Kloppers, WC 2003), fisieke handeling, en die rede waarom dit telkens die beste keuse vir dié betrokke erediens is. Dit gaan in die erediensvoorbereiding om veel méér as die "maak van 'n preek". Die erediens behoort 'n gemeenskaplike geloofservaring van die hele gemeente in besondere ontmoeting met God en met mekaar te word.

Beplanning van eredienste behoort dus so ver vooruit as moontlik gedoen te word. Deur van die erediens 'n fees (Cornehl et al 1993) te maak wat sentreer rondom die groot feestye in die kerkjaar, 'n gemeenteverjaarsdag, en dies meer, kan die nodige beplanning vooruit gedoen word (Otto 1988:330). Geen mens of gemeente kan egter op 'n voortgaande spanningslyn van buitengewone feeste funksioneer nie. Soos in musiek die spanningsmomente gedra én verlig word deur die ontspanningsmomente, behoort daar in 'n gemeente se lewe ook balans te wees. Voller eredienste moet afgewissel word met stiller eredienste. Dit beteken nié dat sekere eredienste of selfs sekere tye in die kerkjaar feesloos is nie! Dit beteken dat die aard van die feeste net verskil (vgl Kloppers 2002a). 'n Intieme ete vir twee kan net so 'n groot fees wees as 'n groot huweliksonthaal - verskillende mense word daardeur verskillend aangespreek. Daar is ook 'n tyd vir beide. Daar is 'n tyd vir 'n gemeente om 'n groot fees te hou, en daar is 'n tyd vir 'n gemeente om stil te word.

\section{Literatuurverwysings}

Adam, A 1992. Foundations of liturgy: An introduction to its history and practice. Collegeville, MN: Pueblo Press.

Assmann, J \& Sundermeier, T (Hrsg) 1991. Das Fest und das Heilige: Religiöse Kontrapunkte zur Alltagswelt. Gütersloh: Gütersloher Verlagshaus.

Assmann, J 1991. Der zweidimensionale Mensch: Das Fest als Medium des kollektiven Gedächtnisses, in Assmann \& Sundermeier 1991:13-30.

Balentine, S E 1999. The Torah's vision of worship. Minneapolis, MN: Fortress Press. Barnard, M \& Post, P (red) 2001. Ritueel bestek: Antropologische kernwoorden van de liturgie. Zoetermeer: Meinema.

Barnard, M 2000. Liturgiek als wetenschap van christelijke riten en symbolen. Intreerede Universiteit van Amsterdam, Amsterdam.

Barnard, M 1998. De heilige Schrift, in Oskamp \& Schuman 1998:195-209.

Bastian, H 1991. Auge und Ohr, Sehen und Hören: Eine Revision theologischer Mediendidaktik, in Zilleßen et al 1991:339-352.

Bell, C 1997. Ritual: Perspectives and dimensions. New York: Oxford University Press.

Berger, R 1987. Kleines liturgisches Lexikon. Freiburg: Herder.

Best, Thomas F \& Heller, Dagmar 1996. Eucharistic worship in ecumenical contexts: The Lima liturgy - and beyond. Genève: WCC Publications. 
Bethge, E 1967. Bonhoeffer: Eine Biografie. München: Kaiser.

Brueggemann, W 1997. Theology of the Old Testament: Testimony, dispute, advocacy. Minneapolis, MN: Fortress.

Cilliers, J H 2003. Die plek en funksie van die wet in die erediens. NGTT44 (1 \& 2), 29-37.

Commissie voor het Dienstboek van het Samenwerkingsorgaan voor de eredienst 1998. Dienstboek - een proeve. Schrift - Maaltijd - Gebed. Zoetermeer: Boekencentrum.

Cornehl, P, Dutzmann, M, Strauch, A (Hrsg) 1993. "In der Schar derer die da Feiern:" Feste als Gegenstand praktisch-theologischer Reflexion. Göttingen: Vandenhoeck.

Chandlee, H E 1983. The Liturgical Movement, in Davies J G (ed), A New Dictionary of Liturgy and Worship, 307-313. London: SCM.

Daiber, K-F, Dannowski H et al 1978. Gemeinden erleben ihre Gottesdienste. Gütersloh: Gütersloher Verlagshaus.

Daiber, K-F 1992. Gottesdienst unter den Bedingungen der gegenwärtigen Gesellschaft. Für den Gottesdienst 39(40), 9-20.

Davies, J G (ed) 1983. A New Dictionary of Liturgy and Worship. London: SCM.

Earey, M \& Myers, G 2001. Common worship today: An illustrated guide to common worship. London: Harper Collins.

Ehrensperger, A 1996. In Stille und Vertrauen liegt eure Kraft: Erfahrungen mit Schweigen und Stille im Horizont des Gottesdienst. Liturgisches Jahrbuch 46, 139-157.

Evangelisch Lutherische Kirche Deutschlands (EKD) 1993. Evangelisches Gesangbuch (EG). Göttingen: Vandenhoeck.

Evangelisch-Reformierten Kirchen der Deutschsprachigen Schweiz 1995. Arbeitsbericht und Gesangbuchentwurf. Zürich: TVZ.

Evangelisch-Reformierten Kirchen der Deutschsprachigen Schweiz 1998. Reformiertes Gesangbuch. Zürich: Theologischer Verlag.

Grethlein, C 1998. Segen und Segnen: Eine systematische-theologische Grundlegung. Stuttgart: Kohlhammer.

Grisbrooke, W J 1983. Kyrie, Litany, in Davies, J G (ed), A New Dictionary of Liturgy and Worship, 291-292; 305-307. London: SCM.

Harnoncourt, P 1994. Der Kalender, in Harnoncourt, P en Auf der Maur, H-J, Feiern im Rhythmus der Zeit, 2,1, 9-63. Regensburg. (Gottesdienst der Kirche. Handbuch der liturgiewissenchaft 6,1.)

Heimbrock, H 1993. Gottesdienst: Spielraum des Lebens. Weinheim: Deutscher Studien.

Heymann, D von (Hrsg) 1983. Handwörterbuch des Pfarramts. 8. Aktualisierung. München: mvg.

Holze, F 1992. Phantasievoll Gottesdienst feiern. Göttingen: Vandenhoeck.

Honders, A C 1988. Liturgie: Barsten en breuken. Kampen: Kok.

Immink, F G 1995. Schriftgebruik in de kerkdiens. Praktische Theologie 22, 516-531.

Immink, F G 1998. Een dubbele beweging, in Oskamp \& Schuman 1998:76-89.

Immink, F G 1998. Schuldbelijdenis en decaloog, in Oskamp \& Schuman 1998:185193.

Jenny, M 1968. Die Einheit des Abendmahlsgottesdienstes bei den elsässichen und schweizerischen Reformatoren. Zürich: TVZ. 
Jenny, M 1970. Die Zukunft des evangelischen Kirchengesanges. Zürich: TVZ. Josuttis, M 1991. Der Weg in das Leben: Eine Einführung in den Gottesdienst auf verhaltenswissenschaftlicher Grundlage. München: Kaiser.

Josuttis, M 1997 (1982). Der Gottesdienst als Ritual, in Wintzer, F (Hrsg), Praktische Theologie. 5.Aufl. Neukirchen: Vluyn, 40-53.

Kloppers, E C 2005. Kerkliedere vir 'n nuwe generasie: 'n Liturgies-himnologiese ontwerp onder voorwaarde van die ekumene. DMus Proefskrif, Universiteit van Pretoria.

Kloppers, E C 2003a. Die erediens as Gesamtkunstwerk. NGTT 44(1\&2), 80-89.

Kloppers, E C 2003b. Verkondiging deur musiek: 'n Aspek van kreatiewe geloofskommunikasie. HTS 59, 65-84.

Kloppers, E C 2003c. Vernuwing in die kerklied: Die nuwe Liedboek van die Kerk 2001. Acta Theologica 23(1), 71-82.

Kloppers, E C 2003d. Veni, veni, o oriens ... Die erediens as kommunikatiewe handeling gerig op oriëntering, uitdrukking, verandering en verbintenis. In die Skriflig 37(1) 115-127.

Kloppers, E C 2003e. Die invloed van 'n postmoderne tydsgees op die kerklied: enkele rigtingwysers. NGTT 44(3\&4), 320-329.

Kloppers, E C 2003f. Singend is die geloof in sy element ... Gemeentesang as kommunikatiewe handeling. Acta Theologica 23(2), 136-145.

Kloppers, E C 2003g. Postmodernisme, nostalgie en die himniese geheue. STILET 15 (2), 2003.

Kloppers, E C 2003h. Noem my jou metafore ... Metaforiese taal as geloofstaal. LITERATOR 24(1), 69-82.

Kloppers, E C 2002a. Transendering van die alledaagse: Die erediens as fees. Praktiese Teologie in Suid-Afrika 17(2), 61-74.

Kloppers, E C 2002b. Die kreatiewe inrigting van die liturgie. Vir die Musiekleier 29, 12-18.

Kloppers, E C 2001. Nuwe tekste, vertalings, liturgiese vorms en hersienings, opgeneem in Liedboek van die Kerk 2001. Kaapstad: NG Kerk-Uitgewers.

Kloppers, E C 2000a. Ubi caritas et amor deus ibi est: Die pastorale funksie van die kerklied. Praktiese Teologie in Suid-Afrika 15(2), 99-111.

Kloppers, E C 2000b. Book Review: Best, T F \& Heller, D (eds), Eucharistic worship in ecumenical contexts: The Lima Liturgy - and beyond. HTS 56, 322.

Kloppers, E C 1999a. Kerkmusiek - 'n beskeie bydrae? in Van Wyk 1999:286-299.

Kloppers, E C 1999b. Die Gesangboek van die Reformierte Kirche in Switzerland, in Vir die Musiekleier 26, 13-16.

Kloppers, E C 1997. Liturgiese musiek as kommunikatiewe handeling in 'n postmoderne era. DTh-Proefskrif, Universiteit van Suid-Afrika.

Kloppers, E C 1996. Resensie: Strydom W M L 1994, "Sing nuwe sange nuut gebore": Liturgie en lied. HTS 52, 219-221.

Kloppers, E C 1995. Liturgical music: Worship or war? Dialog 34, 199-206, herdruk in HTS 53, 172-184.

Kloppers, E C 1994. Riglyne vir sinvolle vernuwing van liturgiese musiek. Ongepubliseerde studiestuk: Predikantevergadering Ned Herv Kerk 1994.

Kloppers, E C 1994. Liturgiese koorsang as wyse van kerklike verkondiging: 'n Prinsipiële besinning vanuit hermeneuties-homiletiese perspektief. HTS 50, 583-609. 
Kloppers, E \& W 2003. Veni Creator Spiritus: Liturgiewerkboek I \& II. Pretoria: Trio.

Kloppers, W C 2003. Wanneer die beelde uit die oog geneem word ... Teks en beeld: 'n Teologiese probleem. HTS 59, 2003, 85-97.

Klostermann, F \& Zerfass, R 1973. Praktische Theologie heute. München: Kaiser.

Krüger, $\mathrm{H}$, et al 1987. Ökumene Lexikon: Kirchen. Religionen. Bewegungen. Frankfurt: Otto Lembeck.

Küppers, K 1987. Gottesdienst II (Liturgie, Messe, Agende) kath. Sicht, in Krüger H, et al, Ökumene Lexikon. Kirchen. Religionen. Bewegungen, 505-507. Frankfurt: Otto Lembeck.

Küppers, K 1987. Gebet, Fürbitte, in Krüger et al 1987:427-428.

Lamberts, J 1985. De vernieuwde liturgie van de eucharistieviering en de actieve deelneming. Leuven: Peeters.

Lukken, G 1999. Rituelen in overvloed: Een kritische bezinning op de plaats en de gestalte van het christelijke ritueel in onze cultuur. Baarn: Ten Have.

Luth, J R et al 2001. Het kerklied: Een geskiedenis. Zoetermeer: Boekencentrum.

Liedboek van die Kerk 2001. Kaapstad: NG Kerk-Uitgewers.

Maritz, F 2001. Response. Konteks November 2001, 12-13

Maritz, F 2003. Gesang 201. Wat 'n wonderlike Afrikaanse loflied! Konteks, November 2003:13.

Maxwell, W D 1983. Reformed worship, in Davies et al 1983:458-460.

Mc Kim, D K (ed) 1992. Major themes in the Reformed tradition. Grand Rapids, MI: Eerdmans.

Möller, C 1988. Gottesdienst als Gemeindeaufbau: Ein Werkstattbericht. Göttingen: Vandenhoeck.

Monshouwer, D 1998. Sabbat en Sondag, in Oskamp en Schuman (reds), De Weg van de liturgie, 100-107. Zoetermeer: Meinema.

Müller, K-F 1955. Das Ordinarium Missae. Leitourgia II, 1-45.

Mumm, R 1987. Liturgische Bewegung I, in Krüger et al, Ökumene Lexikon: Kirchen. Religionen. Bewegungen, 762-763. Frankfurt: Otto Lembeck.

Neunheuser, B 1987. Liturgische Bewegung II, in Krüger et al, Ökumene Lexikon: Kirchen. Religionen. Bewegungen, 764-765. Frankfurt: Otto Lembeck.

Noordmans, O 1986. De kerk en het leven, in Verzamelde werken, Deel VI. Kampen:Kok.

Oskamp, P 2001. Zegenen, in Barnard, M \& Post, P (red), Ritueel bestek: Antropologische kernwoorden van de liturgie, 205-216. Zoetermeer: Meinema.

Oskamp, P \& Schuman, N 1998. De weg van de liturgie: Tradities, achtergronden, praktijk, 205-216. Zoetermeer: Meinema.

Otto, G 1988. Handlungsfelder der Praktischen Theologie: Praktische Theologie Band 2. München: Kaiser.

Peeters, B 2001. Zwijgen, in Barnard, M \& Post, P (red) 2001, Ritueel bestek: Antropologische kernwoorden van de liturgie, 155-161. Zoetermeer: Meinema.

Rothfahl, W 2001. Das Abendgebet musikalisch gestalten, in Innehalten im Tageskreis, 146-153.

Saliers, D E 1993. Worship as theology: Foretaste of glory divine. Nashville, TN: Abingdon. 
Schmidt-Lauber, H-Ch 1987. Gottesdienst I (Liturgie, Messe, Agende) evang. Sicht, in Krüger $\mathrm{H}$, et al, Ökumene Lexikon: Kirchen. Religionen. Bewegungen, 502505. Frankfurt: Otto Lembeck.

Schmidt-Lauber, H-Ch 1995. Liturgiewissenschaft in Theologie und Praxis der Kirche. Göttingen: Vandenhoek.

Stefan, H-J 1995. Arbeitsbericht, in Arbeitsbericht und Gesangbuchentwurf. Zürich:TVZ, 7-36.

Stock, A 2001. Litanieën, in Barnard \& Post 2001:309-316.

Stollberg, D 1983. Gottesdienst, in Von Heymann, D (Hrsg), Handwörterbuch des Pfarramts, 1-40. 8. Aktualisierung. München: mvg.

Strydom, W M L 1994. "Sing nuwe sange, nuutgebore": Liturgie en lied. Bloemfontein: Departement Musiek, Universiteit van die Vrystaat.

Tomkins, O 1983. Ecumenical worship, in Davies, J G (ed), A New Dictionary of Liturgy and Worship, 220-222. London: SCM.

Tongeren, L van 2001. Tijd, in Barnard \& Post 2001:69-76.

Tongeren, $L$ van 2001. Bidden: 14 Bidden in stilte en eigentijdse taal, in Barnard \& Post 2001:200-201.

Van der Merwe, $\mathrm{H}$ 2003. Vernuwing in die erediens: Liturgiese moontlikhede in die Liedboek. Die Hervormer 1 April 2003, bl 5.

Van Nijen, J 1998. Kyrie eleison/Gloria in excelsis, in Oskamp \& Schuman 1998:176184.

Van Wyk, D J C 1999. 20ste eeu Hervormde Teologie. Pretoria: Sentik.

Verein zur Herausgabe des Gesangbuchs der Ev.-ref. Kirchen der deutschsprachigen Schweiz 2001. Werkheft zum Gesangbuch 4. Innehalten im Tageskreis. Morgen - Mittag - Abend - Nacht. Zürich:TVZ.

Viljoen, M 1999. Die tweeslagtige kerksangpraktyk van die Nederduitse Gereformeerde Kerk: 'n Historiese perspektief op die eietydse vraagstuk. Acta Academica 31(3), 94-126.

Vrijlandt, M A 1995. Laat eens wat van je horen: Over responsies in de eredienst. Zoetermeer: Boekencentrum.

Webber, R E 1985. Worship is a verb. Waco: Word.

Wegman, H 1991. Riten en Mythen: Liturgie in de geschiedenis van het christendom. Kampen: Kok.

Wolterstorff, N 1992. The Reformed liturgy, in Mc Kim, D K (ed), Major themes in the Reformed tradition, 273-303. Grand Rapids, MI: Eerdmans.

Wyss-Jenny, E 1999. Mit Kindern singen. Lieder, Kanons, Rufe aus dem neuen Gesangbuch. Zürich:Gottesdienst \& Musik.

Zee, W R van der 1992. Van alle tijden en plaatsen: Voor gesprek en onderricht over de liturgie. Zoetermeer: Meinema. 